\title{
Forenames and Surnames in Spain in 2004
}

\author{
Pablo Mateos ${ }^{1}$ and Ken Tucker ${ }^{2}$ \\ ' University College London, UK \\ ${ }^{2}$ Carleton University, Canada
}

This paper quantifies the corpus of forenames and surnames in Spain in 2004 using the telephone directory. It describes their frequency patterns, major measurable characteristics, and gives some geographical distributions, international comparisons, and historical explanations. The research presented here is set in a context of a broader study of the quantitative properties of the corpus of personal names in several countries undertaken by Tucker. Amongst the most significant findings are a much more highly skewed distribution towards the most popular surnames than in other countries, the permanence of language regions since the Middle Ages, and important differences in top Hispanic names frequencies between five countries across the Atlantic. It is also suggested that the innovative techniques presented here, combining geographical and statistical analysis of names and their language of origin, opens up enormous possibilities for multidisciplinary work on onomastics.

\section{Introduction}

The aim of this paper is to quantify the corpus of forenames and surnames in Spain in 2004 using a broad population register such as the telephone directory. It describes their frequency patterns, major measurable characteristics, and gives some geographical distributions and historical explanations. The paper does not seek to provide a history of forename and surname development in Spain and readers may like to read Kremer's brief review (Kremer, 2003). However, in order to understand some of the processes presented here, we need to describe a few major distinctive features of the historic linguistic context and naming conventions in the Iberian Peninsula.

Surnames started to be used in Spain in the tenth century and were well established by the twelfth century (Kremer, 2003), mainly as patronyms that changed with each generation, although they gradually became inherited surnames between the thirteenth and the fifteenth centuries (Faure et al., 200I). Surnames were introduced as a consequence of the reduction in the number of forenames in the Middle Ages, 
and the need to identify people in legal documents. For example, in the tenth century a study found I.3 people per forename, while a century later the same authors found 3 people per forename (Moll, I982). This seemed to be due to the influence of religion, since most forenames were reduced to the most popular saints.

During these five centuries the Iberian Peninsula was settled by several population groups and languages, grouped into five more or less permanent kingdoms; four of them Christian and south-expanding: Galicia-Portugal, Castile-Leon, Basque Country-Navarre, and Aragon-Catalonia, and one Muslim and south-retreating: Al-Andalus. These groups spoke at least nine different languages (eight romance languages plus Basque Arabic) and, although only Castilian (Spanish), Catalan, Galician, Portuguese, and Basque survive today, all have left traces in the surnames found in the Iberian Peninsula. To these we can add surnames from non-Romance languages, Iberic and Germanic, previously spoken in the peninsula, Jewish surnames, and surnames brought from the native languages of former colonies in Latin America and the Philippines, for example: Moztezuma (Tibón, 200I).

With the growing expansion of Castile since the fourteenth and fifteenth centuries, and the political unification from the beginning of the sixteenth century of what now territorially constitutes Spain, the Castilian language, currently also known as Spanish, was imposed to all other kingdoms. Therefore, Castilianization of personal names over several centuries makes it difficult to ascribe all surnames to their original language and form (Kremer, 2003). Castilianization was combined with Christianization, enforced by the Spanish Inquisition since the sixteenth century, that forced many people change their Arab, Jewish, or 'foreign-sounding' surnames to a mainstream Castilian one to avoid persecution. Some of the new Castilian surnames were adopted so frequently by religious converts that they have been identified as typical 'convert surnames'; these are amongst the most frequent surnames found today, as it will be explained later.

History has left a rich and diverse cultural sediment present in today's place names and personal names in all of the twenty-one Spanish speaking countries. However, this paper is concerned only with the personal names of contemporary Spain. For simplicity we will use the overarching term of 'Spanish names' for these forenames and surnames.

The Spanish custom to use two surnames (father's and mother's surnames, see next section) seems to have started around the sixteenth century. According to Faure (200I) this was because the use of two surnames was associated with aristocratic families, and hence it became very fashionable amongst the popular classes or the upcoming bourgeois. In the sixteenth century those with a nobiliary title or their descendants did not have to pay taxes, and many people tried to claim they had aristocratic ancestors (the group of dispossessed 'nobles', known as 'hidalgos', was huge in the seventeenth century, and they were all registered due to tax exception reasons; 'Padrón de Hidalguía'). Therefore, as Spain went into economic decline in the seventeenth century, it seems to have been important to keep both paternal and maternal surnames to identify individuals who might have some sort of 'nobiliary rights' or just to distinguish themselves from the most common surnames. This explanation is similar to that of using double-barrel names in the Anglo-Saxon naming system, of which there are also many examples with combination of Spanish most popular surnames. 
Finally, in the nineteenth century this custom was institutionalized through a Civil Registration Act (I870) which made it mandatory to register births and always use two hereditary surnames, both father's and mother's surname. The act also forbade any change in the spelling of one's family name (Kremer, 2003). This made sure that paternity and maternity of a child was always clear, as well as to identify brothers and sisters of the same marriage. This had important implications in legal issues, for example in hereditary disputes. This was also the time when Spanish surnames were given to all the population of Philippines, then a Spanish colony, together with Cuba and Puerto Rico, before the I 898 war with the US. Today most people in Philippines carry Spanish names, although only 3,000 people speak Spanish in a country of 89 million people (CIA World Fact book).

The 1870 Act stopped the process of Castilianization of surnames, but that of forenames has continued, and was specially reinforced during the Franco dictatorship, when Castilian was the only official language. The restoration of democracy in I975 has brought back into official records the Galician, Catalan, and Basque given name that many citizens were given at birth. The forty-year dictatorship had also a high impact on the surnames that migrated to Latin America from Spain as people emigrated to escape persecution. A high proportion of Catalan and Basque distinct surnames occur among these emigrants.

Finally, the return to democracy and the economic expansion in the last twenty years has seen Spain shift from a net emigrant country in the I960s and I970s to being now the country with the highest rate of immigration in Europe (in 2005 the population grew by 2.I \%, due to immigration, and in the period $200 \mathrm{I}-2006$ by $9 \%$ ) (Instituto Nacional de Estadística, 2006). This process has brought surnames from all over the world to the Iberian Peninsula, especially to the major cities and the Mediterranean coast and the islands.

Most striking is the surge of rare Spanish surnames noticed in many population registers of Spanish cities (Instituto de Estadística de la Comunidad de Madrid, 2006), some of which were previously extinct in the peninsula (e.g., Simbaña, Armijos). These are surnames brought back from Latin American countries in a return journey after five hundred years, having been preserved and disseminated across the Atlantic, closing a cycle of worldwide population migration and mixture. This is a fascinating journey that we are only starting to discover today by analyzing surname frequencies.

\section{Main features of the Spanish naming system \\ Spanish surname structure}

To an Anglophone, Spanish surnames look quite complicated, as most Spaniards, and people from Spanish-speaking countries, have two surnames. The nearest equivalent in the Anglophone world would be the hyphenated name such as Smith-Jones.

When a Spanish child is born it usually inherits as its first surname its father's first surname, and as its second surname its mother's first surname. For example, say the father's names, in the Forename-Ist Surname-2nd Surname pattern is:

\section{Esteban Martínez Muñoz}

And his wife's name using the same pattern is 


\section{Pilar Ortiz Molina}

Say they have a child and give her the forename Ana. Then her name using the same pattern would be

\section{Ana Martínez Ortiz}

If they had another child, and called him José, then his name would be:

\section{José Martínez Ortiz}

In this example the children have the same surnames, but the mother and father have surnames that differ from each other and those of their children. For married couples, the tradition is not to change any surname, so groom and bride keep their threecomponent birth name. Every child will inherit the father's first surname and the mother's first surname, usually in that order, although the order can be now changed.

Spanish surnames are thus patrilinearly inherited, as are the Anglo-Saxon ones, but it takes two generations to lose surnames in the matrilineal linage, rather than just one in the Anglo-Saxon system. The advantage of the Spanish system is that one can trace a person to both of his or her parents, which helps researchers in different applications, such as in historic record linkage, as well as pedigree reconstruction in genetic research (Rodríguez-Larralde et al., 2003).

For practical purposes, most people in Spanish-speaking countries just use their forename and first surname: for example, Pablo Mateos, and they only use the full name in official documents or formal situations. Therefore, the second surname is used to avoid potential confusions when the purpose of uniquely identifying a person is important (e.g., Pablo Mateos Rodríguez), just as the 'middle name' (usually the second forename) is used in the Anglo-Saxon system: for example, George William Bush vs. George Bush).

\section{Other features of Spanish names}

The most prominent feature of Spanish surnames is the presence of the ending '-ez', which dominates most surnames, with fourteen out of the top twenty most frequent surnames ending in '-ez' or its derivatives. This ending is the patronymic form in old Castilian, and it was attached to the forename of the father (e.g., Fernández was the son of Fernando). A variation of this ending in Galician and Portuguese is '-es', which commonly serves to distinguish the origin of names between languages. However, name corruptions between '-ez' and '-es' endings, in both directions, are frequent in Spanish-speaking Latin America and even more in the US (e.g., Hernandes instead of Hernandez, or Valdez or Cortez instead of Valdes or Cortes) since the letters 's' and ' $z$ ' are pronounced exactly the same in Latin America and the south of Spain. Hispanic surnames of this form in the US, other than a minority of Portuguese origin, are Anglicizations of the ending '-ez' into an '-es'.

Another important feature of Spanish names is the high frequent of toponyms, which Faure et al. (200I) quantify as $58 \%$ of the surnames in their dictionary. Of these, a high proportion of toponyms come from Basque and Catalan place names ( $28 \%$ and $17 \%$ of the total surnames respectively), and while the former group's 
surnames are still located mostly in the Basque country, the latter's are present in parts of the south of Spain, explained by major repopulation settlements in the south during the Middle Ages (Faure et al., 200I).

\section{Quantitative analysis of forename and surname frequencies}

The data for this article was sourced from the Spanish 2004 telephone directory. The data represents II.8 million telephone lines with up to two surname fields and one forename field; some entries had only one surname. Although the telephone directory contained I2.6 million residential telephone lines, 0.8 million opted out of the public version, which could introduce a small bias in this analysis. Assuming one person for every telephone line and given the Spanish population in 2004 to be 43.2 million (Instituto Nacional de Estadistica, 2006), the data represents about one entry for every 3.6 people, which is typical for telephone data, and represents a reasonable sample of over $27 \%$.

The data was presented in either all upper-case, or in lower-case with upper-case initial letters, as in MÁRIA DEL CARMEN and Mária Del Carmen; all data was converted to the latter format.

The analysis follows the pattern established in Tucker (200I, 2002, and 2007) for other national distributions of surnames and forenames. The top hundred forenames and surnames are listed. Graphs of percentage of population against percentage of names and population against occupied frequency for both surnames and forenames are given.

\section{Spanish forenames}

There were no gender indicators in the forename data and the assigned indicators for only the top hundred forenames have been added here. Table I gives the list of the top hundred forenames by count, with count, rank, and gender (F/M). The top eight forenames are masculine, and overall $64 \%$ of the names and $75.3 \%$ of the telephone subscribers in the top hundred forenames are masculine, which is common for such tables drawn from telephone data.

Graph I shows the plot of percentage the population against percentage of forenames. This graph is typical for national distributions of forenames.

Graph 2 shows the population against occupied frequency for forenames. As there is no sex tag in the data supplied, the graphs are for males and females combined. The forename occupied frequency graph exhibits the same shape and distortion of the First Quasi-Line (from $\mathrm{x}=6$ to about $\mathrm{x}=\mathrm{I} 60$ ) as seen in the UK Electoral Roll graphs (Tucker, 2007). The overall form, however, is exactly as expected and shows a clear Zipfian distribution following a power law (Zipf, I949).

\section{Spanish surnames}

In this paper the two surnames will be analyzed as individual surnames as with any other country but, additionally, the surnames in the first surname group will be compared with those of the second surname group to see what differences there are, 
TABLE 1

TOP HUNDRED SPANISH FORENAMES BY RANK

\begin{tabular}{|c|c|c|c|c|c|c|c|}
\hline Name & Count & Rank & F-M & Name & Count & Rank & F-M \\
\hline lose & 444066 & 1 & M & Pilar & 51501 & 33 & $\mathrm{~F}$ \\
\hline Antonio & 388249 & 2 & $M$ & Andres & 50179 & 34 & $M$ \\
\hline Manuel & 338917 & 3 & $M$ & Maria Dolores & 47544 & 35 & $\mathrm{~F}$ \\
\hline Francisco & 306218 & 4 & M & Santiago & 46720 & 36 & M \\
\hline Juan & 214048 & 5 & M & Maria Teresa & 46412 & 37 & $\mathrm{~F}$ \\
\hline Pedro & 129133 & 6 & $M$ & Emilio & 46399 & 38 & $M$ \\
\hline lose Luis & 128727 & 7 & M & lavier & 45559 & 39 & M \\
\hline Jesus & 127249 & 8 & M & Julian & 44809 & 40 & M \\
\hline Maria & 126576 & 9 & $\mathrm{~F}$ & Concepcion & 44753 & 41 & $\mathrm{~F}$ \\
\hline Carmen & 118138 & 10 & $\mathrm{~F}$ & Juan Antonio & 44339 & 42 & $M$ \\
\hline Angel & 114272 & 11 & M & Julio & 41148 & 43 & M \\
\hline Luis & 112671 & 12 & M & Ana Maria & 40855 & 44 & $\mathrm{~F}$ \\
\hline Miguel & 109741 & 13 & M & Ana & 40782 & 45 & $\mathrm{~F}$ \\
\hline Rafael & 108028 & 14 & M & Felix & 40119 & 46 & M \\
\hline Jose Antonio & 105790 & 15 & M & Alfonso & 40057 & 47 & M \\
\hline Jose Maria & 100548 & 16 & M & Juan Carlos & 39600 & 48 & M \\
\hline Maria Del Carmen & 90275 & 17 & $\mathrm{~F}$ & Salvador & 39387 & 49 & M \\
\hline Fernando & 86526 & 18 & M & Maria Luisa & 39121 & 50 & $\mathrm{~F}$ \\
\hline Vicente & 82888 & 19 & M & Mercedes & 39009 & 51 & $\mathrm{~F}$ \\
\hline Josefa & 79591 & 20 & $\mathrm{~F}$ & Tomas & 38489 & 52 & M \\
\hline Jose Manuel & 72161 & 21 & M & Eduardo & 36905 & 53 & M \\
\hline Ramon & 70488 & 22 & M & Agustin & 36895 & 54 & M \\
\hline Carlos & 69212 & 23 & M & Manuela & 35730 & 55 & $\mathrm{~F}$ \\
\hline Isabel & 65053 & 24 & $\mathrm{~F}$ & Mariano & 34820 & 56 & $M$ \\
\hline Francisco lavier & 64296 & 25 & M & Juana & 34698 & 57 & $\mathrm{~F}$ \\
\hline Joaquin & 62078 & 26 & M & Rosario & 34685 & 58 & $\mathrm{~F}$ \\
\hline Enrique & 60917 & 27 & M & Teresa & 34443 & 59 & $\mathrm{~F}$ \\
\hline Dolores & 59775 & 28 & $\mathrm{~F}$ & Ricardo & 34080 & 60 & $M$ \\
\hline Francisca & 57883 & 29 & $\mathrm{~F}$ & Pablo & 32545 & 61 & $M$ \\
\hline Antonia & 55705 & 30 & $\mathrm{~F}$ & Alberto & 32308 & 62 & $M$ \\
\hline Miguel Angel & 53394 & 31 & $M$ & Juan Manuel & 31417 & 63 & $M$ \\
\hline Juan Jose & 52305 & 32 & $M$ & Domingo & 31314 & 64 & $M$ \\
\hline
\end{tabular}


TABLE 1 (Continued)

\begin{tabular}{|c|c|c|c|c|c|c|c|}
\hline Name & Count & Rank & F-M & Name & Count & Rank & F-M \\
\hline Jaime & 31090 & 65 & M & Maria Pilar & 22275 & 83 & $\mathrm{~F}$ \\
\hline Maria Jose & 30201 & 66 & $\mathrm{~F}$ & Alfredo & 22261 & 84 & M \\
\hline Rosa & 30119 & 67 & $\mathrm{~F}$ & Julia & 21908 & 85 & $\mathrm{~F}$ \\
\hline Maria Isabel & 29595 & 68 & $\mathrm{~F}$ & Maria Del Pilar & 21270 & 86 & $\mathrm{~F}$ \\
\hline Encarnacion & 29090 & 69 & $\mathrm{~F}$ & Rosa Maria & 21230 & 87 & $\mathrm{~F}$ \\
\hline Ignacio & 28080 & 70 & $M$ & Sebastian & 20690 & 88 & M \\
\hline Diego & 27950 & 71 & M & Amparo & 20478 & 89 & $\mathrm{~F}$ \\
\hline Maria lesus & 26556 & 72 & $\mathrm{~F}$ & Eugenio & 20342 & 90 & M \\
\hline Gregorio & 26525 & 73 & M & Gabriel & 20104 & 91 & M \\
\hline Alejandro & 26158 & 74 & M & Lorenzo & 19731 & 92 & M \\
\hline Felipe & 25154 & 75 & M & Roberto & 19575 & 93 & M \\
\hline Daniel & 24910 & 76 & M & Maria Carmen & 18530 & 94 & $\mathrm{~F}$ \\
\hline David & 24799 & 77 & M & Elena & 18013 & 95 & $\mathrm{~F}$ \\
\hline Maria Angeles & 24269 & 78 & $\mathrm{~F}$ & Consuelo & 17992 & 96 & $\mathrm{~F}$ \\
\hline Margarita & 24039 & 79 & $\mathrm{~F}$ & lose Miguel & 17586 & 97 & M \\
\hline lose Ramon & 23840 & 80 & M & Guillermo & 17157 & 98 & M \\
\hline Jorge & 22717 & 81 & M & Victor & 17064 & 99 & M \\
\hline Angeles & 22427 & 82 & $\mathrm{~F}$ & Francisco lose & 17014 & 100 & $M$ \\
\hline
\end{tabular}

if any. For convenience we will call the first group of surnames surnameI and the second group surnamez.

Table 2 lists the top hundred surnames in the first surname group, including count and rank, by ascending rank order. The equivalent table for the second surname group is virtually a carbon copy of the first and not much would be added by reproducing it here. Rather, the difference in rank of the second surname group is included in Table 2. The first eighteen entries are identical; Romero is ranked nineteenth in the first surname group; in the second surname group it is ranked nineteenth minus the difference which is $\mathrm{I} 9-(-\mathrm{I})=$ 2oth. Likewise Gutiérrez is ranked in the second surname group $20-(+\mathrm{I})=$ I 9 th .

It is not surprising that the distributions for the first surname group and second surname group are very similar as both are drawn from the same population group. There are some differences between the two groups as $347,895(2.9 \%)$ people in the telephone directory do not have two surnames, but just one, which is usually surnamer. This occurs with foreign persons of non-Spanish-speaking countries, due to privacy protection attitudes of certain subscribers, or just because of errors in the data collection process.

Table 3 lists the top hundred surnames, counted by rank regardless whether the surname was used in the first or second surname position. The first twenty-five are 


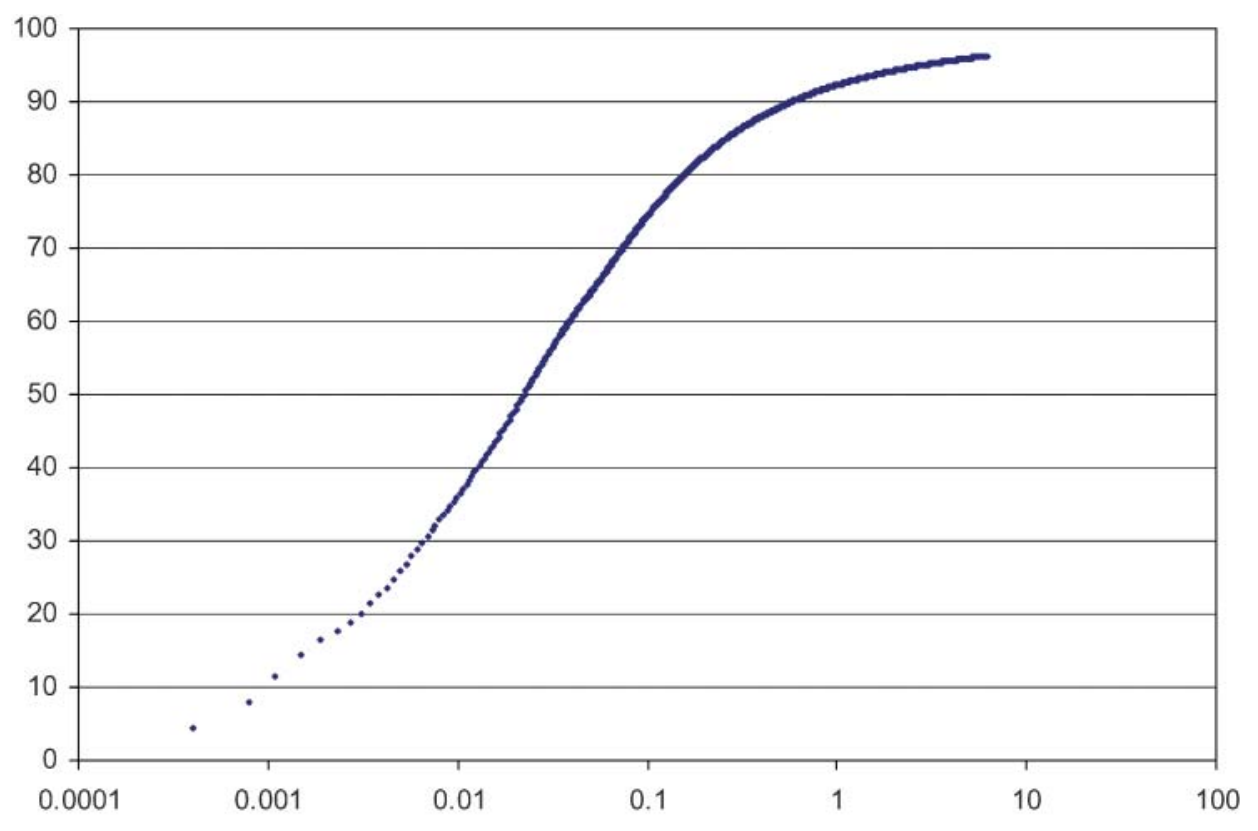

GRAPH 1 Percentage population against percentage of forenames (logarithmic scale)

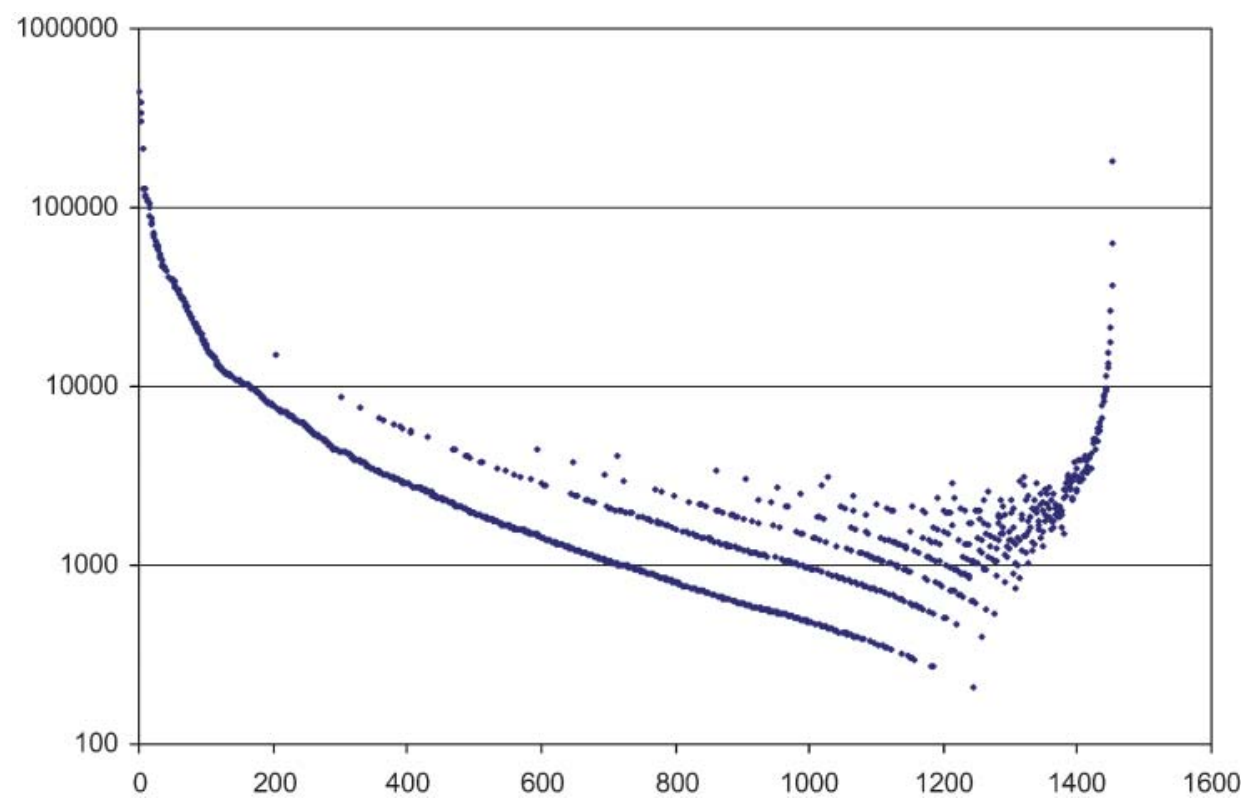

GRAPH 2 Population against occupied frequency for forenames 
TABLE 2

THE TOP HUNDRED SURNAMES IN THE FIRST POSITION

\begin{tabular}{|c|c|c|c|c|c|c|c|}
\hline Surname & Count & Rank & Difference & Surname & Count & Rank & Difference \\
\hline Garcia & 404150 & 1 & 0.0 & Molina & 30201 & 33 & -8.0 \\
\hline Fernandez & 249983 & 2 & 0.0 & Ramirez & 29846 & 34 & -3.0 \\
\hline Gonzalez & 248769 & 3 & 0.0 & Rubio & 29748 & 35 & -1.0 \\
\hline Rodriguez & 241057 & 4 & 0.0 & Morales & 29581 & 36 & -2.0 \\
\hline Lopez & 233814 & 5 & 0.0 & Delgado & 29502 & 37 & 2.0 \\
\hline Martinez & 224887 & 6 & 0.0 & Ortiz & 26249 & 38 & -7.0 \\
\hline Sanchez & 216267 & 7 & 0.0 & Marin & 25496 & 39 & -9.0 \\
\hline Perez & 209572 & 8 & 0.0 & Iglesias & 24271 & 40 & -7.0 \\
\hline Martin & 139762 & 9 & 0.0 & Santos & 22824 & 41 & -9.0 \\
\hline Gomez & 130565 & 10 & 0.0 & Garrido & 22436 & 42 & -7.0 \\
\hline Ruiz & 96419 & 11 & 0.0 & Castillo & 22243 & 43 & -15.0 \\
\hline Hernandez & 91153 & 12 & 0.0 & Núñez & 22134 & 44 & -7.0 \\
\hline Jimenez & 91148 & 13 & 0.0 & Calvo & 21295 & 45 & -7.0 \\
\hline Diaz & 88011 & 14 & 0.0 & Prieto & 21069 & 46 & -8.0 \\
\hline Alvarez & 80681 & 15 & 0.0 & Lozano & 20925 & 47 & -8.0 \\
\hline Moreno & 79530 & 16 & 0.0 & Cruz & 20415 & 48 & -20.0 \\
\hline Muñoz & 73569 & 17 & 0.0 & Medina & 20309 & 49 & -7.0 \\
\hline Alonso & 59837 & 18 & 0.0 & Vidal & 20285 & 50 & -11.0 \\
\hline Romero & 52728 & 19 & -1.0 & Diez & 20095 & 51 & -2.0 \\
\hline Gutierrez & 51601 & 20 & 1.0 & Cano & 19843 & 52 & -5.0 \\
\hline Navarro & 46638 & 21 & -1.0 & Gallego & 19347 & 53 & -6.0 \\
\hline Torres & 41576 & 22 & -3.0 & Pascual & 18916 & 54 & -12.0 \\
\hline Dominguez & 40779 & 23 & 0.0 & Peña & 18859 & 55 & -7.0 \\
\hline Gil & 40038 & 24 & -2.0 & Guerrero & 18715 & 56 & -4.0 \\
\hline Vazquez & 38892 & 25 & 1.0 & Vega & 18067 & 57 & -8.0 \\
\hline Ramos & 37091 & 26 & -1.0 & Herrero & 17875 & 58 & -6.0 \\
\hline Serrano & 36863 & 27 & -1.0 & Mendez & 17842 & 59 & -4.0 \\
\hline Blanco & 35318 & 28 & -1.0 & Leon & 17742 & 60 & -7.0 \\
\hline Sanz & 31671 & 29 & -4.0 & Ferrer & 17595 & 61 & -22.0 \\
\hline Suarez & 31040 & 30 & -1.0 & Nieto & 16628 & 62 & -7.0 \\
\hline Ortega & 31038 & 31 & -3.0 & Fuentes & 16475 & 63 & -7.0 \\
\hline Castro & 30290 & 32 & -7.0 & Marquez & 16281 & 64 & -15.0 \\
\hline
\end{tabular}


TABLE 2 (Continued)

\begin{tabular}{|c|c|c|c|c|c|c|c|}
\hline Surname & Count & Rank & Difference & Surname & Count & Rank & Difference \\
\hline Cortes & 16172 & 65 & -12.0 & Flores & 13633 & 83 & -11.0 \\
\hline Ibañez & 16080 & 66 & -15.0 & Saez & 13498 & 84 & -5.0 \\
\hline Campos & 16032 & 67 & -9.0 & Mora & 13430 & 85 & -13.0 \\
\hline Vicente & 15941 & 68 & -10.0 & Arias & 13216 & 86 & -5.0 \\
\hline Carrasco & 15885 & 69 & -11.0 & Velasco & 13029 & 87 & -5.0 \\
\hline Herrera & 15849 & 70 & -1.0 & Santana & 12585 & 88 & 4.0 \\
\hline Caballero & 15787 & 71 & -4.0 & Andres & 12498 & 89 & -16.0 \\
\hline Cabrera & 15575 & 72 & -2.0 & Marti & 12325 & 90 & -55.0 \\
\hline Montero & 15213 & 73 & -9.0 & Reyes & 12294 & 91 & -13.0 \\
\hline Lorenzo & 15053 & 74 & 1.0 & Merino & 12289 & 92 & -7.0 \\
\hline Esteban & 14486 & 75 & -10.0 & Moya & 12202 & 93 & -16.0 \\
\hline Aguilar & 14481 & 76 & -17.0 & Izquierdo & 12138 & 94 & -8.0 \\
\hline Gimenez & 14369 & 77 & -23.0 & Carmona & 11998 & 95 & -16.0 \\
\hline Crespo & 14180 & 78 & -10.0 & Bravo & 11986 & 96 & -1.0 \\
\hline Soler & 14179 & 79 & -43.0 & Casado & 11900 & 97 & -18.0 \\
\hline Hidalgo & 14153 & 80 & -7.0 & Pardo & 11703 & 98 & -10.0 \\
\hline Pastor & 14082 & 81 & -9.0 & Soto & 11700 & 99 & -15.0 \\
\hline Duran & 13847 & 82 & -14.0 & Miguel & 11614 & 100 & -32.0 \\
\hline
\end{tabular}

identical to Table I and as expected there is very little difference between the two tables, and all one hundred are Spanish surnames. Garcia is the most popular surname by far $(6.8 \%$ of the population bear it as either surnamer or surname2). Its etymological origin comes from the patronym Garcia, which has not been used as a forename since the sixteenth century, but it must have been a very popular forename in Spain during the Middle Ages (Faure et al., 200I)

Graph 3 shows the plot of percentage of the population against the logarithm of percentage of surnames in either position. The graphs, not shown, for the first position surnames and that of the second position surnames are virtually identical and closely mirror that of Graph 3. They run slightly below that of Graph 3: at O.I\% of the surnames in the first position the plot is about $50 \%$ of the population, whereas we will see that the combined plot is at $55 \%$. Of course all graphs axiomatically reach the IOO, IO० point.

This graph is not quite typical for national distributions of surnames; particularly the bulge between $0.001 \%$ and $0.01 \%$ of surnames. The 1997 UK Electoral Roll (Tucker, 2003) has a more typical 'S' curve also observed for the US, Canadian, and UK surnames distributions. Table 4 shows a rough comparison between the UK plot and that of the Spanish Data. 
TABLE 3

THE TOP HUNDRED SURNAMES IN EITHER POSITION

\begin{tabular}{|c|c|c|c|c|c|}
\hline Surname & Count & Rank & Surname & Count & Rank \\
\hline Garcia & 813257 & 1 & Rubio & 59458 & 33 \\
\hline Fernandez & 503142 & 2 & Ramirez & 59370 & 34 \\
\hline Gonzalez & 499596 & 3 & Delgado & 59145 & 35 \\
\hline Rodriguez & 482448 & 4 & Morales & 59034 & 36 \\
\hline Lopez & 467681 & 5 & Castro & 58945 & 37 \\
\hline Martinez & 449954 & 6 & Ortiz & 52792 & 38 \\
\hline Sanchez & 433030 & 7 & Marin & 50412 & 39 \\
\hline Perez & 421997 & 8 & Iglesias & 48321 & 40 \\
\hline Martin & 278261 & 9 & Garrido & 45025 & 41 \\
\hline Gomez & 261776 & 10 & Santos & 44190 & 42 \\
\hline Ruiz & 193130 & 11 & Nuñez & 43931 & 43 \\
\hline Hernandez & 182808 & 12 & Calvo & 42705 & 44 \\
\hline Jimenez & 181206 & 13 & Lozano & 42088 & 45 \\
\hline Diaz & 176485 & 14 & Castillo & 41944 & 46 \\
\hline Alvarez & 161674 & 15 & Prieto & 41709 & 47 \\
\hline Moreno & 158435 & 16 & Diez & 40607 & 48 \\
\hline Muñoz & 145791 & 17 & Medina & 40575 & 49 \\
\hline Alonso & 119004 & 18 & Vidal & 40211 & 50 \\
\hline Romero & 105603 & 19 & Cano & 39535 & 51 \\
\hline Gutierrez & 103776 & 20 & Gallego & 38130 & 52 \\
\hline Navarro & 92302 & 21 & Guerrero & 37290 & 53 \\
\hline Torres & 82578 & 22 & Pascual & 36976 & 54 \\
\hline Dominguez & 81473 & 23 & Cruz & 36776 & 55 \\
\hline Gil & 79895 & 24 & Peña & 36538 & 56 \\
\hline Vazquez & 77755 & 25 & Mendez & 35490 & 57 \\
\hline Serrano & 73552 & 26 & Herrero & 35020 & 58 \\
\hline Ramos & 73544 & 27 & Vega & 34825 & 59 \\
\hline Blanco & 69810 & 28 & Ferrer & 34815 & 60 \\
\hline Suarez & 63257 & 29 & Leon & 34138 & 61 \\
\hline Sanz & 62803 & 30 & Nieto & 32752 & 62 \\
\hline Ortega & 61904 & 31 & Fuentes & 32670 & 63 \\
\hline Molina & 60172 & 32 & Cortes & 32434 & 64 \\
\hline
\end{tabular}


TABLE 3 (Continued)

\begin{tabular}{|c|c|c|c|c|c|}
\hline Surname & Count & Rank & Surname & Count & Rank \\
\hline Marquez & 31973 & 65 & Flores & 27414 & 83 \\
\hline Campos & 31882 & 66 & Saez & 27288 & 84 \\
\hline Caballero & 31863 & 67 & Arias & 26803 & 85 \\
\hline Ibañez & 31793 & 68 & Mora & 26267 & 86 \\
\hline Herrera & 31534 & 69 & Velasco & 26172 & 87 \\
\hline Carrasco & 31284 & 70 & Santana & 25689 & 88 \\
\hline Vicente & 31163 & 71 & Merino & 24401 & 89 \\
\hline Cabrera & 30876 & 72 & Izquierdo & 24329 & 90 \\
\hline Lorenzo & 30112 & 73 & Moya & 24287 & 91 \\
\hline Montero & 30085 & 74 & Bravo & 24234 & 92 \\
\hline Gimenez & 29429 & 75 & Reyes & 24067 & 93 \\
\hline Esteban & 28648 & 76 & Carmona & 24050 & 94 \\
\hline Hidalgo & 28460 & 77 & Marti & 23914 & 95 \\
\hline Aguilar & 28386 & 78 & Andres & 23895 & 96 \\
\hline Pastor & 27921 & 79 & Redondo & 23542 & 97 \\
\hline Soler & 27776 & 80 & Pardo & 23209 & 98 \\
\hline Crespo & 27638 & 81 & Vila & 23162 & 99 \\
\hline Duran & 27575 & 82 & Casado & 23062 & 100 \\
\hline
\end{tabular}

The Spanish surname distribution is thus even more weighted to the popular surnames than that of the UK. Spanish society thus seeks comparatively more use of the popular surnames. This exception has been also found in a comparative study by Scapoli et al. (2007) who analyzed the surname frequency distributions of eight major European countries Austria, Belgium, France, Germany, Italy, Netherlands, Spain and Switzerland.

These authors found that the top eight most popular 'European surnames' are all Spanish, and there are thirty-nine Spanish surnames in the top hundred surnames of the countries studied, when its population only represents ${ }_{3} 3 \%$ of the study. This fact can be attributed to three major causes. The first one is the pattern of Christian repopulation of Spain since the early Middle Ages, from relatively small Christian communities in the north to a territorial expansion throughout the Iberian Peninsula and to America, thus expanding an originally small pool of local surnames. The second is the pressure of the Spanish Inquisition which forced Muslim and Jewish converts to adopt popular Castilian surnames (Faure et al., 200I), as well as the afore-mentioned Castilianization of other surnames. The third is a phenomenon of 'surname drift' (propagation of the same local popular surnames) that has not been counteracted by enough internal migration, and therefore a symptom of surname 


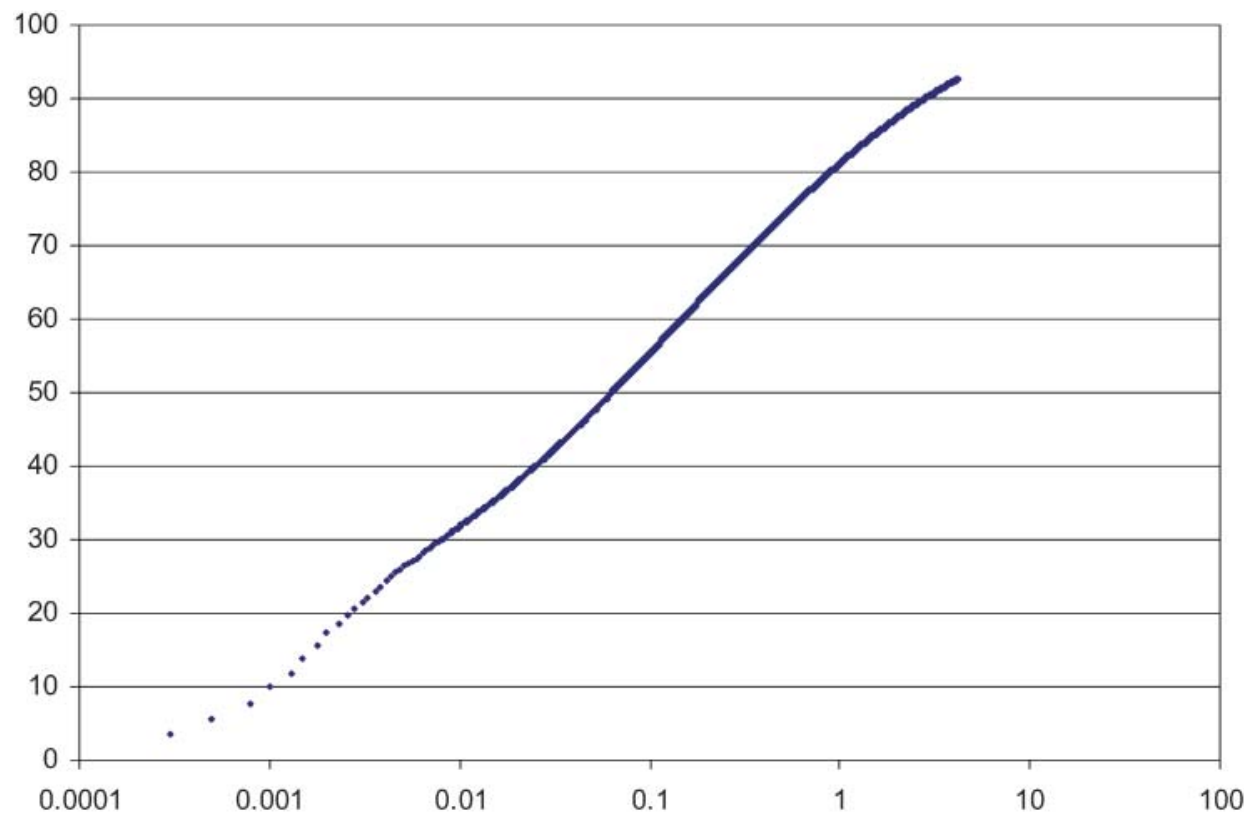

GRAPH 3 Percentage population against percentage of surnames in either position

TABLE 4

PARTIAL COMPARISON OF THE SPANISH AND UK SURNAME PLOTS IN PERCENTAGES

\begin{tabular}{lcc}
\hline Surnames & \multicolumn{2}{c}{ Population } \\
\cline { 2 - 3 } & Spain & UK \\
\hline 0.001 & 10 & 5 \\
0.01 & 32 & 20 \\
0.1 & 55 & 47 \\
1.0 & 80 & 80 \\
\hline
\end{tabular}

inbreeding in many areas (that is, a high frequency of marriages between the same surnames, also known as isonymy) (Scapoli et al., 2007).

Graph 4 shows the Population by Occupied Frequency of the SurnameI; again, the same style graph for Surnamez is virtually identical and is not shown. Graph 5 shows the population by occupied frequency of the combined surnames.

Both Graphs 4 and 5 are typical for national surname distributions and are clearly Zipfian.

\section{The geographical distribution of surnames}

The maps shown in Figure I show the geographical distribution of surnames in Spain according to their language region of origin; Basque, Catalan and Valencian, 


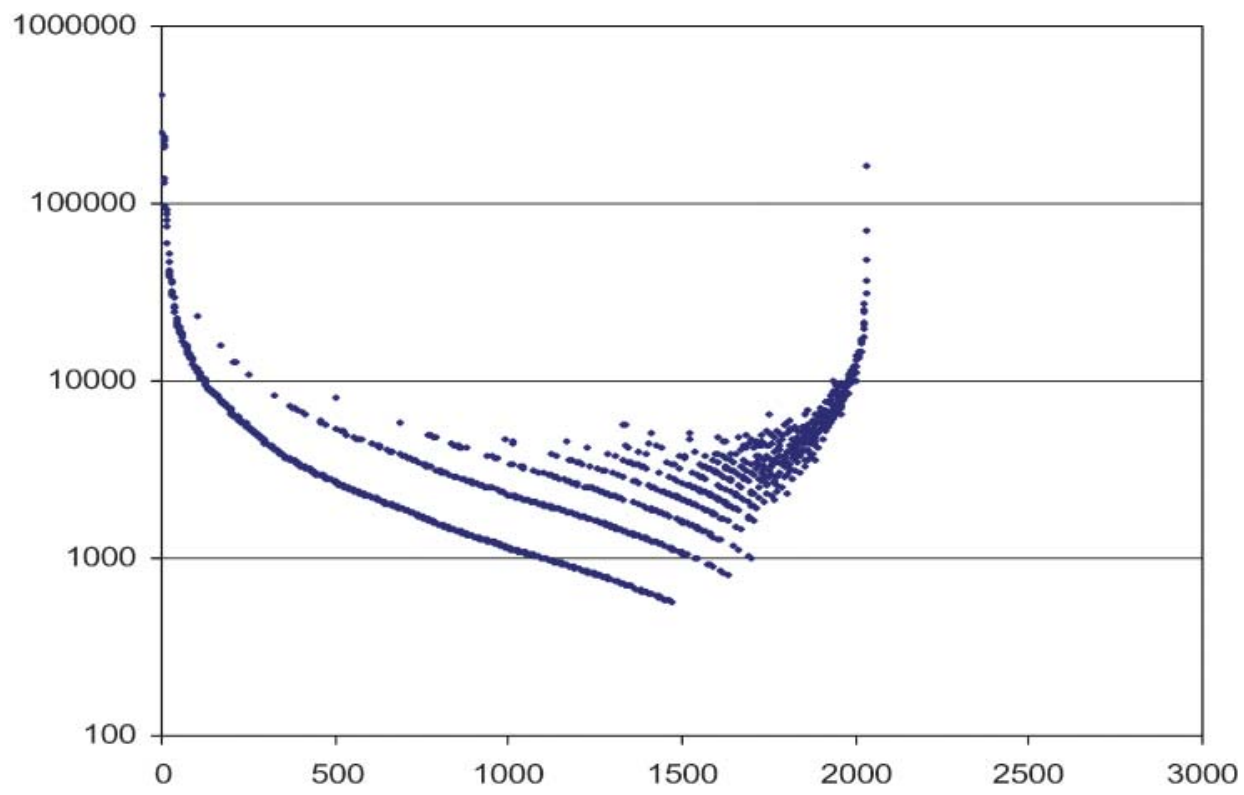

GRAPH 4 Population against occupied frequency for surname1

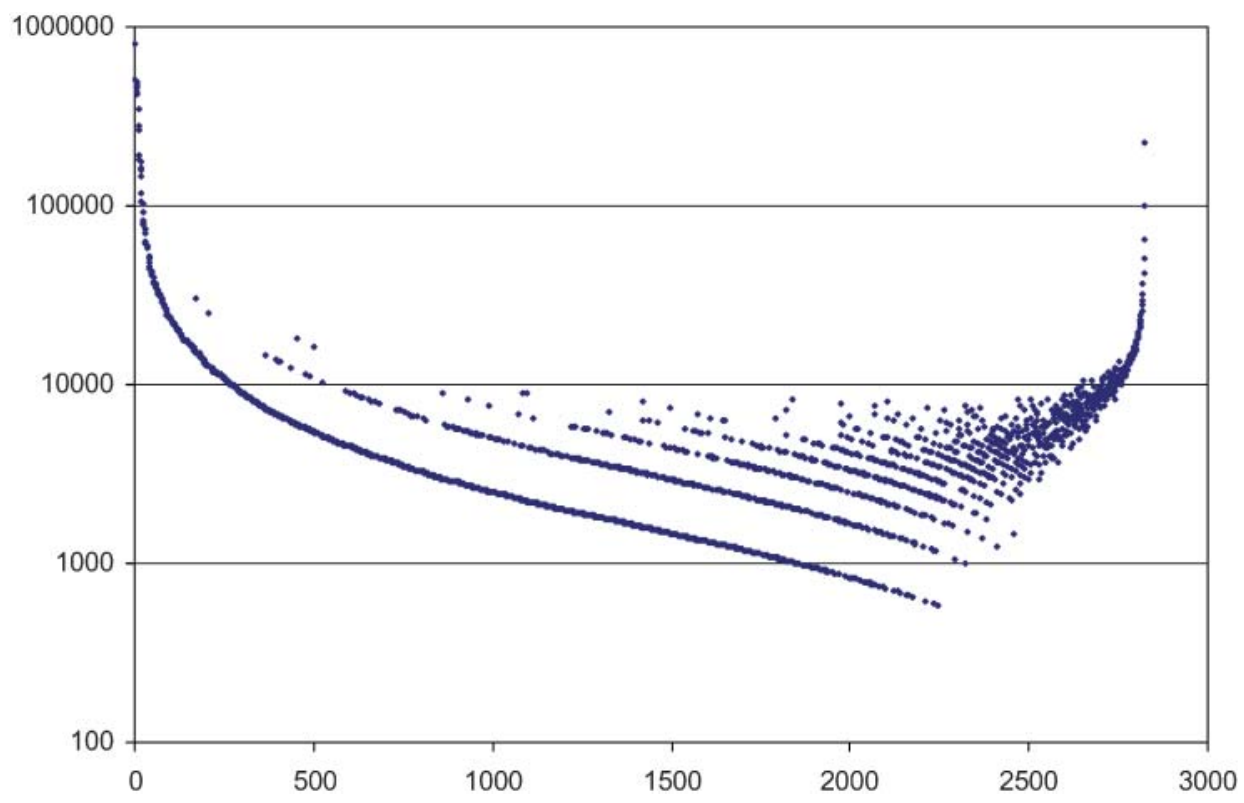

GRAPH 5 Population against occupied frequency for the combined surnames 
Galician, Castilian, and 'Other Spanish' which includes Spanish surnames with no particular regional or linguistic origin. The method to identify the language of origin for each Spanish surname is explained in Mateos (2006). The power of these five maps is that they summarize the history of the Middle Ages in Spain up to the sixteenth century, and how slowly those population patterns have evolved since then. The striking fact that one needs to remember is that these maps do not come from a historical atlas, but they have been built from the surnames frequencies of the Spanish 2004 telephone directory. The maps show the five quintiles of the frequencies of each of the surname categories by postal area, from I (lower quintile) to 5 (highest quintile).

The history of the four languages of Spain, their origins in the north third of the country and their southwards expansion are explained by these maps. The maps show the southwards expansion of Castilian from its core in the north-north-west, of Catalan from the north-east along the Mediterranean coast and islands (and south of Italy and Sardinia, should they also be on the map), the core of Galician language in the interior of Galicia (north-east) and onto Portugal (not seen on the map except for a few overspills along the border). They also show the uniqueness of Basque surnames and the relatively smaller interaction with their neighbors, a fact well studied in genetics (Cavalli-Sforza, 1997). Finally, a map of all other Spanish surnames reflects the inverse of the above maps, the repopulation of the southern half of Spain through the Middle Ages, the generation of new surnames, and the general spread of a much more mixed population that also went on to the Canary Islands (see map insets in Fig. I), and beyond on to Latin America. The maps also show the areas where more population mix and interaction have occurred, especially during the twentieth century, eroding the 'bedrock' of local surnames established in Middle Ages. This is evident in the Catalonian coast and the province of Barcelona, leaving the highest incidence of Catalan surnames to the interior. A similar pattern is observed in the Balearic Islands, Valencia, and Galicia. This is the power of unveiling a sort of 'demographic geomorphology', deposited during nearly ten centuries, through the geography of contemporary surname frequencies.

\section{International comparisons of Spanish names}

Graph 6 shows a comparison of the frequencies of the top hundred surnames in five Spanish-speaking countries: Spain, Argentina, Mexico, Venezuela, and the US. The sources for these countries are as follows: Spain, the telephone directory featured in this paper; Mexico, a list of the top hundred surnames from the 2006 electoral roll, supplied to the authors by the Mexican Electoral Commission (Instituto Federal Electoral) under a Freedom of Information Act request; Argentina, hundred most frequent surnames from the $200 \mathrm{I}$ electoral roll (Cámara Nacional Electoral) published in Dipierri (2005); Venezuela, a list of the forty most frequent surnames from the I99I electoral roll (Consejo Supremo Electoral) published by Rodriguez-Larralde (2000); US, a list of surname frequency data from the I990 Census published online (US Census, 2006).

There is a clear distinction between the slope of the frequency curves of Argentina and the US distributions, much less steep than those of the other three countries. This is explained by a much higher rate of surname immigration from different countries 

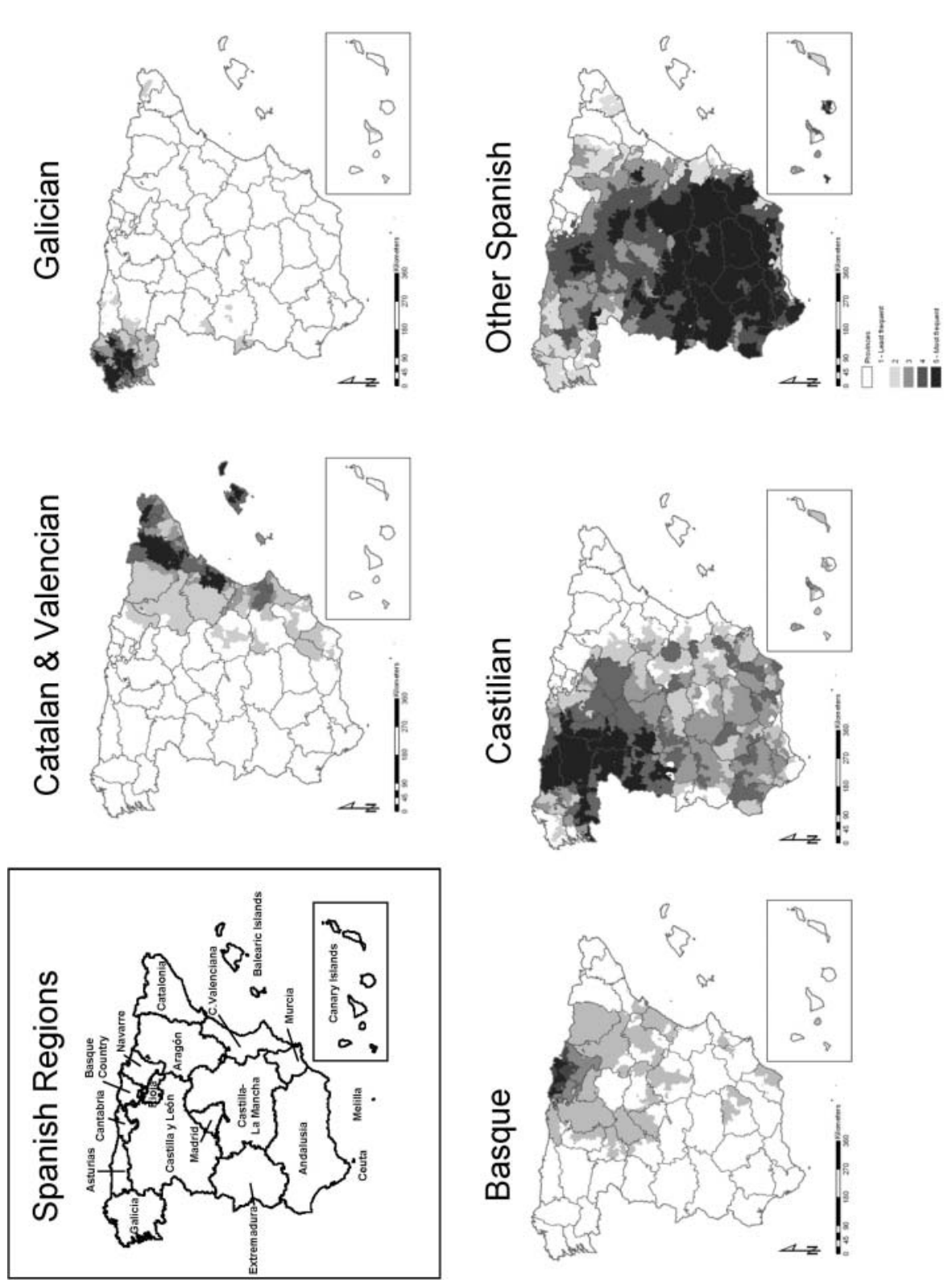

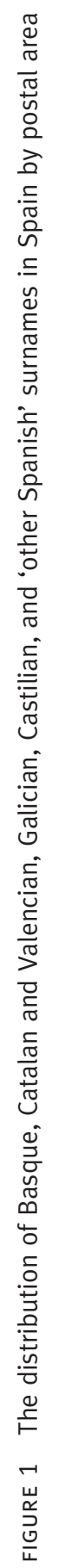




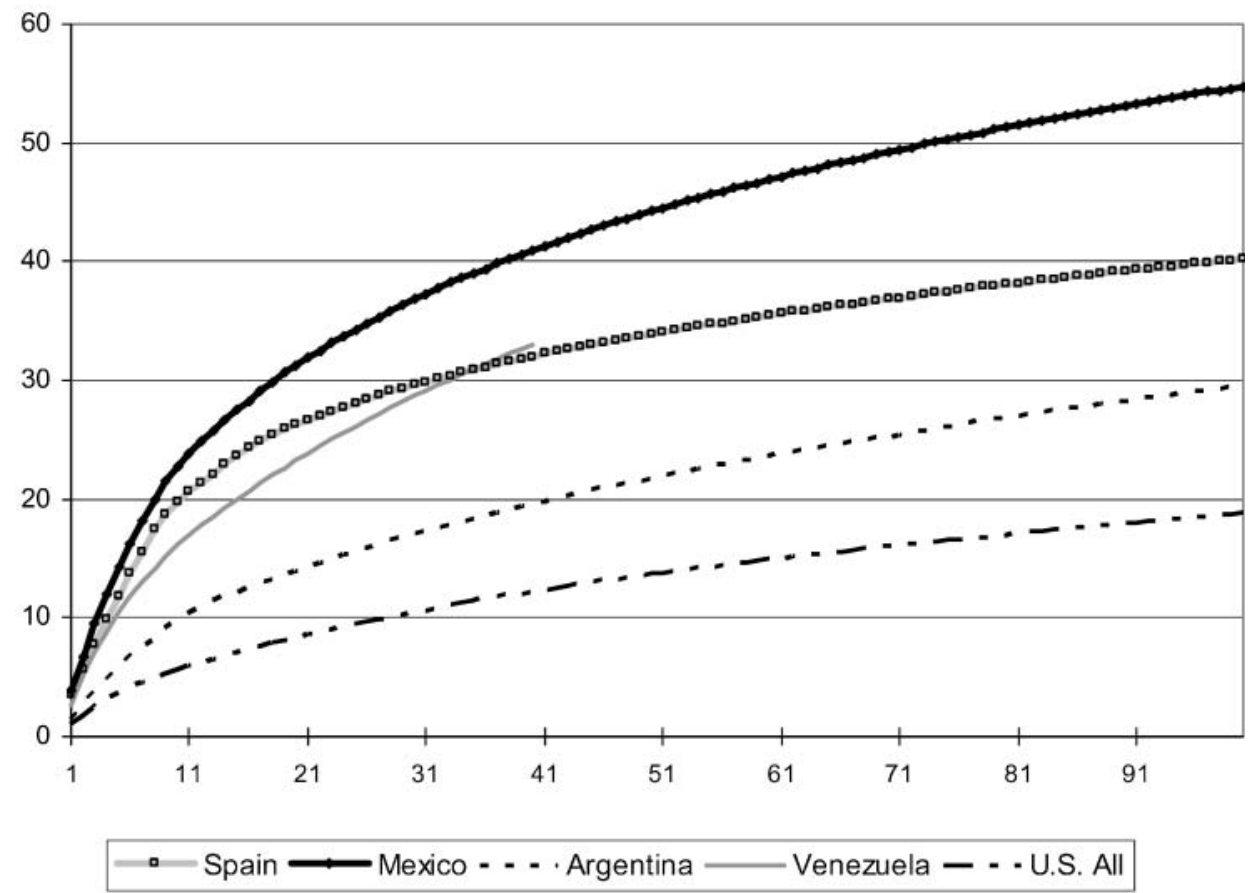

GRAPH 6 The percentage population represented by the top 100 surnames in Spain, Mexico, Venezuela, Argentina, and the US

and languages to both countries, whereas Spain, Mexico, and Venezuela have not been substantially exposed to non-Spanish surnames. Secondly, the Mexican population is highly concentrated in a few surnames, $50 \%$ of them sharing just 74 surnames, and the top three surnames covering 9.5\% (Hernández, García and Martínez). This must be due to the combined fact that a few surnames have been imposed to the pre-Hispanic population by the Spanish colonial army and the church (Hernández means the son of Hernán, the forename of the conqueror of Mexico; Hernán Cortés), and that a low internal migration rate and low intermarriage between ethnic and socio-economic groups have produced high surname drift (propagation of the same popular surnames).

The top US Hispanic surnames are not included in Graph 6, but if they were the line would run very close to the Mexican line. These data were derived from the list of Hispanic surnames and the overall surname frequency data from the r990 Census published online (US Census, 2006). The close similarity between the Mexican and the US Hispanic surname distributions point to a high proportion of the Hispanic surnames in the US having come from Mexico rather than the rest of Latin America, plus a reflection of the population settlements in the south-western states prior to the I848 US-Mexican border.

\section{Summary}

The characteristics of the forenames and surnames in Spain discussed in this paper can be summarized into a set of common features. The forename frequency 
distribution of the contemporary population of Spain follows a similar pattern as that of other countries studied by Tucker. The literature seems to indicate this was not the case in the Middle Ages, with most of the population sharing just a small pool of religiously prescribed forenames, so there has been a phenomena of rapid expansion in the forenaming practices. The surname frequency distribution presents a unique pattern, with a much higher concentration of the population in the most popular surnames than that found in other countries, an anomaly that other authors have also found (Scapoli et al., 2007). This peculiar surname frequency distribution could be explained by three combined processes. First, the pattern of Christian repopulation of the Iberian Peninsula and population expansion since the early Middle Ages from a small pool of patronyms in the north. Secondly, due to an imposed process of name change, on the one side because of the pressure of the Spanish Inquisition against non-Christians, and on the other due to a process of Castilianization of surnames. Thirdly, a phenomenon of 'surname inbreeding', that is, a high frequency of marriages between the same surnames (also known as isonymy) not counteracted by migration in many areas. Amongst other features of Spanish names, the unique naming system of two surnames does not produce any substantial difference between the frequency distribution of parental and maternal surnames (both of them coming from males two generations up the genealogical chain), even when it better reflects both sexes in the population.

The exploratory geographical analysis of name groups classified by language of origin that has been presented here does indicate the clear potential of using the quantitative analysis of names' geographical distributions to unveil historic population settlement and migration processes. In this case it reveals the original language regions of Spain in the Middle Ages and how these cultural regions are still structuring how populations mix today within still very confined interaction areas. Finally, a comparison of the frequency distribution the top surnames in five Spanish-speaking countries shows that surnames are a good indicator of how different populations have settled and have mixed between countries, as well as how the naming practices imposed upon former colonies have impoverished the naming heritage of their populations.

In this paper we hope to have unveiled some of the 'quantitative secrets' of Spanish names. Through the set of techniques presented here, we also aimed to introduce to the onomastic community a new field of spatio-temporal quantitative analysis of names to understand past and current population structures through 'name geomorphology'. We believe that linguists, historians, geographers, geneticists, statisticians and demographers should collaborate more closely to unveil a little bit more of how we came to be what we are today.

\section{Appendix: data processing issues Data hygiene: errors in the data}

The errors in the data files are typical for large data files but indicative of the poor data hygiene in the gathering process. The errors could have been avoided by the simple expedient of only allowing symbols that appear in forenames and surnames to appear in the data. Errors included the following non-letter symbols (other than 
hyphens) in names: '.', 'o' for 'O', '4', ‘\%', ' '(space). There were also some triple characters in the names.

\section{Diacritical marks}

The data as supplied had very few diacritical marks. No attempt has been made to insert diacritical marks.

\section{Format issues}

The data sets were complicated by the fact that, although Garcia looked liked Garcia, they had been keyed in different forms such that GARCIA, Ioo when added to Garcia, 99 did not always sum to Garcia, I99. The problem was that some of the data were in all capitals, and some were in initial capitals only, and that converting the 'all capitals' format to 'initial capitals only' did not resolve the issue. This data problem was resolved, and the consolidated tables give the totals. However, when comparing the first surnames with the second surnames the 'all capitals' data only has been used. In the case of Garcia, for example, this represents 91\% of the total data, so it is believed that the results are valid.

\section{Bibliography}

Cavalli-Sforza, L. L., I997. 'Genes, Peoples, and Languages,' Proceedings of the National Academy of Sciences, 94(I5): 7719-24.

Dipierri, J. E., Alfaro, E. L., Scapoli, C., Mamolini, E., Rodríguez-Larralde, A., and Barrai, I., 2005. 'Surnames in Argentina: A Population Study through Isonymy,' American Journal of Physical Anthropology, I28: I99-209.

Faure, R., Ribes, M. A., and Garcia, A., 200I. Diccionario de apellidos españoles, Madrid: Espasa Calpe.

Instituto de Estadística de la Comunidad de Madrid, 2006. Guía de nombres y primer apellido de los residentes en la comunidad de Madrid I998-2005.

Instituto Nacional de Estadistica, 2006. Cifras oficiales de población [Official Population Figures]. Available at: http://www.ine.es/prensa/padron_tabla.htm [accessed: I5 February 2007].

Kremer, D., 2003. 'Spanish and Portuguese Family Names,' in Dictionary of American Family Names, ed. P. Hanks, New York: Oxford University Press.

Mateos, P., 2006. 'Segregación residencial de minorías étnicas y el análisis geográfico del origen de nombres y apellidos' [Residential Segregation of Ethnic Minorities and Geographic Analysis of Name Origins], Cuadernos Geograficos, 39(2): 83-IOI.

Moll, F. B., I982. Els llinatges catalans, Mallorca: Moll.

Rodriguez-Larralde, A., Gonzales-Martin, A., Scapoli, C., and Barrai, I., 2003. 'The Names of Spain: A Study of the Isonymy Structure of Spain,' American Journal of Physical Anthropology, I2I: 280-92.

Rodríguez-Larralde, A., Morales, J., and Barrai, I., 2000. Surname Frequency and the Isonymy Structure of Venezuela. American Journal Of Human Biology I2: 352-62.

Scapoli, C., Mamolini, E., Carrieri, A., Rodriguez-Larralde, A., and Barrai, I., 2007. 'Surnames in Western Europe: A Comparison of the Subcontinental Populations through Isonymy,' Theoretical Population Biology, 7I: 37-48.

Tibón, G., 200I. Diccionario etimológico comparado de los apellidos españoles, hispanoamericanos y filipinos, México D.F.: Fondo de Cultura Económica.

Tucker, D. K., 200I. 'Distribution of Forenames, Surnames, and Forename-Surname Pairs in the United States,' Names, 49: 69-96.

Tucker, D. K., 2002. 'Distribution of Forenames, Surnames, and Forename-Surname Pairs in Canada,' Names, $50(2): 105-32$.

Tucker, D. K., 2003. 'An Analysis of the Forenames and Surnames of England and Wales Listed in the UK Census Data,' Onoma, 38: I8I-2I6. 
Tucker, D. K., in press. 'Surname Distribution Prints from the UK 1998 Electoral Roll Compared with Those from Other Distributions,' Nomina, 30: 5-22.

US Census, 2006. Us Census Bureau Geneaology Resources. Available at: http://www.census.gov/genealogy/www/ [accessed: I2 May 2006].

Zipf, G. K., I949. Human Behavior and the Principle of Least Effort, Reading, MA: Addison-Wesley.

\section{Notes on Contributors}

Dr Pablo Mateos is a Lecturer in Human Geography, Department of Geography and Centre for Advanced Spatial Analysis, University College London, UK. His research interests lie within Population Geography, and focus on investigating new ontologies and geographic visualizations of ethnicity, migration and mobility in today's rapidly changing cities and societies. He is developing innovative and multidisciplinary methods, such as name origin analysis, to analyze the spatial forms and social processes that harbor socioeconomic inequalities at neighborhood level, with a view to informing public policy.

Dr D. Kenneth Tucker, Research Fellow, Carleton University, Ottawa, is principally interested in the distribution of given names and surnames, and the need to embed each as objects in electronic systems to eliminate spelling errors by looking up the name rather than attempting to recreate it with the real chance of skipping out of the universe of real names as evidenced by past and contemporary censuses and the like.

Correspondence to: Dr D. Kenneth Tucker, Department of History, Carleton University, II25 Colonel By Drive, Ottawa, ON, KIS 5B6, Canada. Email: posthaus@igs.net 